\title{
The Impact of Political Relations on China's Outward Direct Investment
}

\author{
Lin Zhang, Xiaoqiong Hao
}

\begin{abstract}
A B S T R A C T
Objective: This article relates to the growing amount of literature on the determinants of the location choice of Chinese ODI. The objective of the article is to investigate whether the improvement in political relations will encourage more investment to a host country or not. Also, the article aims to identify the asymmetric impact of political relations in different host countries.
\end{abstract}

Research Design \& Methods: Using information on bilateral events from People's Daily Database and the website of Chinese Ministry of Foreign Affairs, we establish an indicator for bilateral political relations. Then, this article empirically examines the impact of political relations on the location choice for Chinese ODI based on the quarterly data of foreign direct investment of Chinese enterprises from 2003 to 2014 using a fixed effect model.

Findings: Regression results suggest that political relations have a positive and statistically significant effect on Chinese ODI. The relation rises by one unit, it is associated with an increase in Chinese ODI by USD 25.9 million. The results also suggest that Chinese firms would prefer developing host countries which have a good relation with China, especially those with a better legal system.

Implications \& Recommendations: It implies that not all host countries are affected by political relations in the same way. The improvement in the bilateral political relations will increase Chinese ODI to developing countries. In terms of developed host countries, instead of bilateral political relations economic development and the market size are main determinants for Chinese ODI.

Contribution \& Value Added: Instead of describing political relations with a single indicator, we build an indicator based on the political events methodology to analyse the location choice of Chinese ODI by using monthly data to capture the accumulated effect of events on political relations.

\begin{tabular}{ll}
\hline Article type: & research article \\
Keywords: & political relations; China; ODI; institutions; asymmetric \\
JEL codes: & F21, F50 \\
\hline
\end{tabular}

Received: 19 August 2018

Revised:20 October 2018

Accepted: 9 November 2018

\section{Suggested citation:}

Zhang, L., \& Hao, X. (2018). The Impact of Political Relations on China's Outward Direct Investment. Entrepreneurial Business and Economics Review, 6(4), 12-26. https://doi.org/10.15678/EBER.2018.060401 


\section{INTRODUCTION}

Foreign direct investment is an important economic activity for a country to expand to overseas markets, optimise resource allocation and acquire strategic resources. Since the launch of the 'One Belt and One Road' initiative in 2013, China's foreign direct investment has grown rapidly. In 2016, investment was up to USD 196.15 billion, an increase by $34.7 \%$ year-onyear, and the average annual growth rate from 2002 to 2016 was as high as $35.8 \%$ (Statistical Bulletin on China's Outward Foreign Direct Investment, 2016). However, under the increasingly complex international political environment, the country's political risk encountered by Chinese companies during the overseas investment is growing. Especially the recent ChinaUS trade conflict already exerts an adverse impact on Chinese investment to the United States. Due to the setback in economic and trade relations with the U.S., Chinese direct investment in the United States dropped by more than a third (35\%) in 2017 compared with 2016, to USD 29 billion of consummated deals. Of all completed transactions in 2017, more than a half $(60 \%)$ of the value stemmed from the completion of deals announced during the 2016 investment boom. In terms of new activity, the drop was even sharper - the value of newly announced Chinese acquisitions in the US fell to USD 8.7 billion in 2017, a drop of more than $90 \%$ in comparison with 2016 and the lowest level in six years (Hanemann \& Rosen, 2017). Furthermore, the growing regulatory hurdles in the US - mostly more complications getting clearance from the Committee on Foreign Investment in the United States (CFIUS) - may hurt Chinese investors' confidence, too. The impact of changing political relations on Chinese investors is not rare. Since Myanmar's democratic transformation in 2011, the projects of Chinese companies such as the Myitsone hydropower station and MonywaLetpadaung copper mine have been blocked. On March 30, 2015, the new government led by the National League for Democracy was sworn in. In March 2016, the new government of Myanmar adjusted the foreign investment policy and clearly stipulated that river bank dykes and mineral mining are prohibited areas for foreign investment in Myanmar (Du \& Chen, 2016). The above events highlight the importance of studying relations between countries and political risks that affect overseas investment of Chinese companies.

In 2016, China's foreign direct investment showed a rapid growth trend, accounting for $13.5 \%$ of the world's total foreign direct investment from $0.5 \%$ in 2002 , and its volume ranks second in the world for two consecutive years. However, the situation of foreign investment of enterprises is increasingly complex. The replacement power in the host country, the adjustment of internal affairs and diplomacy, and the complexity domestic situation in the host country - they all increase potential risks for a company's overseas investment. Therefore, the main objective of the article is to measure the impact of bilateral political relations on China's ODI and to quantify the change in Chinese overseas investment due to the change in political relations with a host country. Besides, we also hope to identify the causal mechanism of political relations affecting FDI flows to different host countries.

The remainder of the article is arranged as follows. Section 2 describes literature related to our research and our possible contribution to the literature. Section 3 focuses on building the national relations indicator, as well as the explanation of variables and data sources. Section 4 empirically analyses the impact of bilateral relations on the location choice of Chinese investment using a fixed effect model and discusses empirical results, and Section 5 concludes the article. 


\section{LITERATURE REVIEW}

The political relations among nations are an external political relationship based on national security, strengthening economic exchange and enhancing the influence of the country. It includes diplomacy, war, alliances, trade, cultural exchange, participation in international organisations and other activities ( $\mathrm{Hu}, 2016)$. Along with the expansion of Chinese overseas investment and an increase in political risks, scholars began to pay attention to the impact of bilateral political relations on investment location choice and the scale of investment.

\section{Casual Mechanism between Political Relations and FDI}

A growing amount of literature in the fields of economy and politics has investigated the effects of political relations on FDI. The majority of the research demonstrates that a good relationship between home and host countries facilitates FDI (Nigh, 1985; Bandelj, 2002; Desbordes \& Vicard, 2009; Desbordes, 2010; Fornes \& Butt-Philip, 2011; Zhang, Jiang, \& Zhou, 2014). A few studies find that a deteriorating international relationship cannot influence MNEs' investment decision due to the effect of sunk cost (Davis \& Meunier, 2011). Other studies find that whether political relations have an impact on direct investment depends on other factors, such as economic development level, institutional quality, etc. (Li \& Vashchilko, 2010; Desbordes \& Vicard, 2009).

There are four casual mechanism between political relations and FDI. Firstly, the literature on the impact of political relations on corporate investment in the early period believed that the focus on the political aspects of investment environment came mainly from investors' subjective perception of the political environment of the host country. Nigh (1985) believes that home investors themselves have to pay close attention to interstate cooperation or the impact of conflicts on the host country's business environment. The statistical analysis of US manufacturing FDI finds that national conflicts have significantly reduced US investment, while inter-nation cooperation increases it. Secondly, the rational expectations of investors will influence the ways in which interstate conflicts change investment behaviours. Forward-looking investors integrate their anticipation on how political conflicts affect expected return into investment decisions. Once the risk of political conflicts is expected to be high, they may reduce investment before conflicts occur. But the reality is that companies cannot perfectly assess the risks involved and can only make adjustments ex post when facing unexpected violent acts (Li, 2006; 2008). Li (2006) finds that unanticipated interstate war reduces the chance of a country as an investment location, but has little effect on the amount of FDI inflow. Thirdly, the national relations (military conflict and security alliance) will change the government's policy towards international business and investor expectations of political risk, which in turn will influence the choice of the host country (Li \& Vaschilko, 2010). Biglaiser and DeRouen (2007) prove the above mechanism by analysing how the presence of U.S. troops encourages U.S. capital inflows to 126 developing countries. Because they believe U.S. troops in host countries signal positive relations and possibly alliances between the U.S. and host countries, ensuring investment stability available to U.S. firms. Finally, bilateral relations affect investment in host countries by changing the cost of entry and exit. A good bilateral relationship lowers the productivity cutoff for firm entry from one home country while conflict raises it (Li, Vaschilko, \& Vaschilko, 2010). 


\section{Political Relations and Chinese ODI}

Political relation as an important bilateral institutional arrangement has become an important reference for investment decisions. Since political relationship has a complementary effect on institutional environment of host countries, good relations can significantly promote the profits of enterprises' ODI. Especially for host countries with poor institutional environment, the complementary effect is more significant (Liu \& Yang, 2016). In addition, scholars tend to describe bilateral relations with the establishment of diplomatic relations, high-level officials' visits, the number of friendly cities, interstate conflicts, and signing Bilateral Investment Treaties (BITs). Findings are that the longer the establishment of diplomatic relations between China and the host country and the more friendly cities, the more investment flows from China to the host country. Also, frequent and friendly diplomatic activities are conducive to alleviate the adverse impact of poor institutional environment of the host country on investment (Zhang \& Jiang, 2012). Xiao and Jiang (2014) suggested that state leaders' political interaction has significantly increased the Chinese ODI scale and reduced the relative volatility of investment. In addition, a BIT is considered as a mechanism for host governments to credibly commit not to expropriate investors in the future. Therefore, BITs are effective in promoting FDI inflows to developing countries and may even substitute for weak domestic institutions. Besides, the effect of the entry of a BIT into force of crucially depends on the quality of political relations between the signatory countries; it increases FDI more between countries with tense relationships than between friendly countries (Neumayer \& Spess, 2005; Desbordes \& Vicard, 2009; Busse, Kniger, \& Nunnenkamp, 2010). Research on Chinese ODI shows that BIT does promote the scale and diversification degree of enterprises' investment (Yang, Liu, \& Zhang, 2016). Moreover, the effect of BIT differs across the institutional environment of a host country, and it plays more important role in promoting investment to countries with poorer institutions (Zong, Lu, \& Wu, 2012). Because good political relations serve as an alternative arrangement to effectively reduce the uncertainty and encourage the investment to host countries with relatively high institutional risks (Pan \& Jin, 2015). Furthermore, the bilateral political relations have a stronger promoting effect in ODI of resource intensive industries, while it does not have a significant promoting effect in the infrastructure industry, which is more vulnerable to bilateral political situation and local governments (Yang et al., 2016).

\section{Political Risks and Enterprises' Overseas Investment}

Some studies focus on how political risks (bureaucratic corruption, political turmoil and terrorism) affect investment. The results show that firms tend to invest in countries with stable government, low corruption, and less to be the target of terrorist attacks (Mancuso, Dirienzoce, \& Das, 2010; Quer, Claver, \& Rienda, 2012; Li \& Liang, 2012; Vladimír, Lenihan, \& Andreosso, 2014). Research on Chinese ODI arrives at similar conclusions that enterprises invest more in countries (regions) with higher political stability. Because the political risks are relatively small, the sound legal system can effectively protect the rights of investors and guarantee the implementation of contracts (Gao, 2011; Xie, 2015; Meng \& Dong, 2015). Although some research has shown that host countries' political risk does not seem to hinder Chinese investment, it does not mean that Chinese investment has a preference for political risks, but because the 'shielding' effect of strategic natural resources of a host 
country on political risks (Wei \& Chen, 2009), or because good political relations between China and host country reduce the political risk (Quer et al., 2012; Li \& Liang, 2012). The higher the host country's political risks, the more companies tend to adopt sequential investments, and investment experience can help companies to avoid and reduce some political risks and improve the ODI probability in that host country (Li \& Qi, 2017).

As to the influence of political relations on enterprises' investment, the existing literature has achieved relatively rich outcomes in the area. But scholars usually describe political relations with a single indicator, including the establishment of diplomatic relations, high-level officials' visits, friendly cities, interstate conflicts, signing BITs, government stability and control of corruption, etc. We believe the above isolated indicator cannot fully reflect the political relations between countries, since it may ignore the changes in relations caused by unexpected events. Therefore, based on the political events methodology by Yan $(2004 ; 2010)$, our article contributes to the growing literature that analyses the location choice of Chinese ODI by using monthly data to capture the accumulated effect of events on political relations.

\section{MATERIAL AND METHODS}

Based on the above related literature, in this article we test the hypothesis that the location choice of Chinese outward investments depends to a large extent on bilateral political relations. Since the institutional quality varies across countries, we also compare the different effects of political relations on Chinese ODI in developing and developed countries.

\section{Variable Measurement and Data}

The variables in this article include China's foreign direct investment flows, political relations, real GDP, real effective exchange rates, openness, and variables for host country institutions (laws and regulations, corruption control). We collected quarterly data from 40 countries (regions) from 2003 to 2014 . Each variable is explained as follows:

\section{Dependent Variable ( $\left.o f d i_{i t}\right)$}

The investment data comes from the China Global Investment Tracker provided by the American Heritage Foundation and the Global Outward Investment Database provided by FDI Markets. The stock data cannot accurately reflect the impact of political relations on current ODI due to the accumulated effect of historical events. Therefore, we use the flow of ODI instead of the stock. We select the top 40 host countries (regions) of China's foreign direct investment which accounts for $94.5 \%$ of the total investment in 126 countries (regions) ${ }^{1}$. We hope to capture the characteristics of China's ODI with the sample.

\section{Main Independent Variables}

Political relations $\left(\right.$ Rela $\left.l a_{i-1}\right)$ : We construct an index for describing bilateral political relations based on the methodology proposed by Yan (2010). Firstly, we select relevant events

\footnotetext{
${ }^{1}$ The 40 countries (regions) are: Argentina, Australia, Belgium, Brazil, Bulgaria, Canada, Egypt, France, Germany, Hong Kong, Hungary, India, Indonesia, Iran, Ireland, Italy, Japan, Kazakhstan, Malaysia, Mexico, Netherlands, Nigeria, Pakistan, Peru, Philippines, Poland, Romania, Russia, Saudi Arabia, Singapore, South Korea, South Africa, Spain, Taiwan, Thailand, Turkey, United Arab Emirates, United Kingdom, United States, Vietnam.
} 
by keywords and then assign scores to each event according to their impact on bilateral relations. The events include but are not limited to the establishment of diplomatic relations, top officials' visits and signing BITs, etc ${ }^{2}$. Secondly, we calculate each event impact score using formula (1). Lastly, we aggregate impact score to get monthly data. We are able to capture the positive or negative impact of each event more accurately by overlapping the impact of historical events on bilateral relations. All bilateral events information comes from People's Daily Database and the website of Chinese Ministry of Foreign Affairs. The events could be dated back as early as October 1949 and the latest data we have is update to December 2014. The formula for event impact is as follows:

where:

$$
I= \begin{cases}\frac{N+P_{0}}{N} I_{0}, & \text { if } I_{0}<0 \\ \frac{N-P_{0}}{N} I_{0}, & \text { if } I_{0} \geq 0\end{cases}
$$

$I$ - indicates the impact score of an event when the relationship between the two countries was at $P_{0}$;

$N$ - is the absolute value of the scope for changes in relations which is 9. For example, declaring war against an ally's enemy or taking the initiative to return the originally occupied territory to each other is considered to have the greatest positive impact on bilateral relations. So events like that score 9. While declaring the independence of a confederation or declaring war against each other indicates the worst bilateral relations which will have a score of -9;

$P_{0}$ - is the initial value of the relationship between two countries when the event happened;

$I_{0}$ - is the assigned score for each event. It is reasonable to think that the impact of the same event will be different when bilateral relations are different.

Take the establishment of a strategic partnership for example, its impact could be much greater when the two countries are hostile towards each other than that when they are very close to each other. Therefore, we adjust the initial assigned score of each event to be the impact score to reflect the above difference.

\section{Control Variables}

1. InGDP is the logarithm of a host country's real GDP. It is an indicator for market size which attracts market oriented FDI. The data comes from the Economist Intelligence Unit (EIU) quarterly Country database.

2. Open shows the openness of a host country. It is calculated with the share of total exports of services and goods to the country's real GDP. The total exports of services and goods are from the quarterly database of EIU.

3. Rate refers to the real effective exchange rate of the host country's currency against China Yuan ${ }^{3}$. It controls the effect of exchange rate fluctuations on investment costs

\footnotetext{
${ }^{2}$ For detailed information on events and their scores please contact the author.

${ }^{3}$ The Real Effective Exchange Rate (REER) is the nominal effective exchange rate (NEER) adjusted with the corresponding relative consumer prices. And NEER is weighted average of bilateral exchange rates in which the weights reflect import competition, direct export competition and third-market export competition. Therefore,
} 
and returns affecting ODI of enterprises. The data comes from the EIU's quarterly Country database. Rates for countries including Argentina, Hong Kong, India, Mexico, Peru, South Africa, Taiwan, Thailand, Turkey, and United Arab Emirates are from the Bank for International Settlements monthly data. The host country's quarterly rate is the rate for the last month in a quarter.

4. Institution measures the host country's institutional quality. Since lack of protection of property rights increases the risk of the expropriation of private assets, and the imperfect market system (such as corruption) may increase the cost of investment. Also, public goods (such as infrastructure) provided by the government rarely reach the standard with poor institutions in a country. All the above affects the expected return on investment (Bloigen, 2005). In addition, Xie (2013) emphasized that a sound legal and institutional environment can be one of the most important attractiveness for investment. Therefore, we select corruption control (corrupt) and rule of law (law) as proxy variables for the quality of institutional environment. Corrupt reflects perceptions of the extent to which public power is exercised for private gain and law reflects perceptions of the extent to which agents have confidence in and abide by the rules of society, and in particular the quality of contract enforcement, property rights, the police, and the courts, as well as the likelihood of crime and violence. The data comes from World Bank's World Governance Indicator (WGI).

Table 1. Descriptive Statistics

\begin{tabular}{|l|r|r|r|r|r|}
\hline \multicolumn{1}{|c|}{ Variables } & \multicolumn{1}{c|}{ Samples } & \multicolumn{1}{c|}{ Mean } & \multicolumn{1}{c|}{ S.D. } & \multicolumn{1}{c|}{ Min } & \multicolumn{1}{c|}{ Max } \\
\hline ofdi & 1,920 & 119.4309 & 414.4027 & 0 & 5312.8 \\
\hline rela & 1,919 & 5.983950 & 1.7378010 & -5 & 8.1 \\
\hline Ingdp & 1,628 & 4.943987 & 1.4871500 & 1.71672 & 9.608425 \\
\hline open & 1,440 & 0.4387731 & 0.34688560 & 0.09052 & 2.129854 \\
\hline rate & 1,728 & 103.6004 & 22.736060 & 29.984 & 185.115 \\
\hline law & 1,440 & 0.6020278 & 0.90414170 & -0.95 & 1.98 \\
\hline corrupt & 1,440 & 0.5760000 & 0.96133740 & -1.09 & 2.22 \\
\hline
\end{tabular}

Source: of data: author's calculation.

Table 1 provides descriptive statistics for the above mentioned variables. Investment flows to a host country ranges from 0 for Argentina in 2003 to 5.3 billion dollars for the United States in the 3rd quarter 2014. The relatively large standard deviation of investment shows a big difference in attracting China's investment in the above countries. Also the large standard deviation of bilateral relations and rate indicates that the interstate cooperation and relative value of currencies are quite different as well. Besides, law and corrupt have relatively small standard deviations.

\section{Estimation Strategy}

Following the discussion on variables above, we formulated the regression model as follows:

$$
\begin{gathered}
\text { ofdi }_{i t}=\beta_{0}+\beta_{1} \text { Rela }_{i t-1}+\beta_{2} \text { Open }_{i t}+\beta_{3} \ln G D P_{i t}+\beta_{4} \text { Rate }_{i t}+ \\
+\beta_{5} \text { Institution }_{i t}+\mu_{i}+\lambda_{t}+\varepsilon_{i t}
\end{gathered}
$$

REER provides a better indicator of the macroeconomic effects of exchange rates than any single bilateral rate (Klau \& Sau Fung, 2006). 
where:

$i, t$ - represent the host country and time (quarter) of the investment;

of $d i$ - is the direct investment flow from China to host countries; Considering the lag effect on investment decisions caused by changes in political relations;

Re $l a$ - is political relations lagged by one quarter;

Open - indicates $i$ host country's openness;

Rate - is the real effective exchange rate for the host country's currency;

Institution - measures host country's institutional quality, including corruption controls and the rule of law;

$\ln G D P$ - is the host country's gross domestic product in the logarithm form in order to alleviate possible heteroskedastic problem;

$\mu_{i}$ - represents unobservable factors that change with the country but do not change over time;

$\lambda_{t}$ - is fixed effect for years;

$\varepsilon_{i t}$ - is error item. In another word, a year fixed effect is controlled to isolate the time trend of investment in case of the estimates are over biased.

Therefore, by controlling both year and country fixed effects, we are able to control the impact of country-specific characteristics and some unobservable time-related factors on investment.

\section{RESULTS AND DISCUSSION}

\section{Benchmark Results}

Table 2 presents results on how bilateral political relations between China and the host countries shape the patterns of Chinese outward investment. We do find that the estimated coefficient for political relations is positive and statistically significant. That is, the improvement of the bilateral relations encourages Chinese enterprises to invest in the host country. Referring to the relation index, we could say that more frequent top officials' visits, establishment of strategic partnership, more friendly cities, signing BIT help to improve bilateral relations, thus promote the investment by reducing transaction costs and uncertainty. We can also infer from the estimation results that if the relation increases by one unit, it is associated with an increase in Chinese ODI by 25.9 million USD (model 6).

We find that the coefficient on open indicates a significantly negative relationship between openness and Chinese ODI due to the substitution effects between trade and investment (Brainard, 1997; Chen, 2010). Given the bilateral relations, the more open the host country, the lower trade costs which may induce enterprises entering into the overseas market via trade instead of investing. Besides, ODI is motivated by resource, market or technology acquiring, so reducing investment costs is not the main reason for Chinese ODI to some countries.

Not surprisingly, the coefficient of host country's GDP is insignificant, which suggests that Chinese investment is not motivated by market-seeking. Law is positively significant at $1 \%$, indicating that improvement in host countries' institutional environment attracts more Chinese investment. In addition, corruption becomes a barrier to foreign investment by raising transaction costs and reducing the public trust in the government as well as the efficiency of bureaucratic agencies. It is consistent with the positive coefficient of corrupt, that better control of corruption contributes to reducing the barriers and attracting more investment. 
Table 2. Full Sample Empirical Results

\begin{tabular}{|c|c|c|c|c|c|c|}
\hline \multirow{2}{*}{ Variable } & \multicolumn{6}{|c|}{ ODI } \\
\hline & (1) & (2) & (3) & (4) & (5) & (6) \\
\hline \multirow[t]{2}{*}{ Relation } & $11.2241^{* *}$ & 21.3527* & $21.2852 *$ & 21.6486* & $23.7001 * *$ & $25.8875^{* *}$ \\
\hline & (3.4483) & (7.9980) & $(7.9800)$ & (8.2525) & (8.0095) & $(6.5834)$ \\
\hline \multirow[t]{2}{*}{ Open } & & $-464.9462 * *$ & $-463.5174 * *$ & $-472.1167 * *$ & $-513.0538 * *$ & $-495.0859 *$ \\
\hline & & (148.4354) & (155.1772) & (157.6862) & (179.5009) & (199.8621) \\
\hline \multirow[t]{2}{*}{$\operatorname{lnGDP}$} & & & 4.0503 & 12.4020 & 6.7586 & -20.4306 \\
\hline & & & (105.9775) & (102.6527) & (111.7993) & (100.8369) \\
\hline \multirow[t]{2}{*}{ Rate } & & & & -0.3996 & -0.7892 & -0.5187 \\
\hline & & & & $(0.4020)$ & $(0.4777)$ & $(0.3356)$ \\
\hline \multirow[t]{2}{*}{ Law } & & & & & $173.7888^{* * *}$ & \\
\hline & & & & & (15.6283) & \\
\hline \multirow[t]{2}{*}{ Corrupt } & & & & & & $119.7468^{* *}$ \\
\hline & & & & & & $(33.8968)$ \\
\hline \multirow[t]{2}{*}{ Constant } & 0.6078 & 46.0366 & 25.9045 & 24.3846 & -7.7890 & 100.9961 \\
\hline & (52.7325) & (135.6766) & (543.4537) & (535.7021) & (641.4615) & (561.0976) \\
\hline \begin{tabular}{|l|} 
Country \\
fixed effect
\end{tabular} & Yes & Yes & Yes & Yes & Yes & Yes \\
\hline $\begin{array}{l}\text { Time fixed } \\
\text { effect }\end{array}$ & Yes & Yes & Yes & Yes & Yes & Yes \\
\hline Sample & 1,919 & 1,439 & 1,439 & 1,439 & 1,439 & 1,439 \\
\hline R-squared & 0.0558 & 0.0783 & 0.0783 & 0.0784 & 0.0797 & 0.0799 \\
\hline
\end{tabular}

Note: Standard errors are in parentheses; ${ }^{* * *}, * *$, and $*$ are significant at the $1 \%, 5 \%$ and $10 \%$ levels respectively.

Source: own study.

We find that the coefficient on open indicates a significantly negative relationship between openness and Chinese ODI due to the substitution effects between trade and investment (Brainard, 1997; Chen, 2010). Given the bilateral relations, the more open the host country, the lower trade costs which may induce enterprises entering into the overseas market via trade instead of investing. Besides, ODI is motivated by resource, market or technology acquiring, so reducing investment costs is not the main reason for Chinese ODI to some countries.

Not surprisingly, the coefficient of host country's GDP is insignificant, which suggests that Chinese investment is not motivated by market-seeking. Law is positively significant at $1 \%$, indicating that improvement in host countries' institutional environment attracts more Chinese investment. In addition, corruption becomes a barrier to foreign investment by raising transaction costs and reducing the public trust in the government as well as the efficiency of bureaucratic agencies. It is consistent with the positive coefficient of corrupt, that better control of corruption contributes to reducing the barriers and attracting more investment. 


\section{Sub-Sample Results}

Considering the availability of data, the full sample is divided into two sub-samples - developing and developed countries or regions ${ }^{4}$. Then we introduced the intersection term of political relations and GDP, political relations and open to examine how relations affects firms' investment via openness.

Table 3. Sub-Sample Results (Institution is proxy by Corrupt)

\begin{tabular}{|c|c|c|c|c|c|c|}
\hline \multirow{2}{*}{ Variable } & \multicolumn{3}{|c|}{ developing countries } & \multicolumn{3}{|c|}{ developed countries } \\
\hline & (1) & (2) & (3) & (4) & (5) & (6) \\
\hline \multirow[t]{2}{*}{ Relation } & $134.9933 * * *$ & $160.2445 *$ & $379.4284 *$ & 9.0251 & 56.0499* & $-192.5730^{*}$ \\
\hline & $(47.2078)$ & $(83.5077)$ & $(219.5083)$ & $(20.1719)$ & $(32.9137)$ & $(98.4793)$ \\
\hline \multirow[t]{2}{*}{ Open } & -432.9531 & 59.8862 & -517.4427 & $-1,106.2840 * * *$ & 218.3152 & $-1,217.2118^{* * *}$ \\
\hline & $(391.3160)$ & $(1,399.9186)$ & (398.1874) & (391.8269) & $(831.1700)$ & $(394.3251)$ \\
\hline \multirow[t]{2}{*}{ Rela $\times$ Open } & & -76.4878 & & & $-195.1982 *$ & \\
\hline & & $(208.5933)$ & & & $(108.0778)$ & \\
\hline \multirow[t]{2}{*}{ InGDP } & -97.2910 & -123.6098 & 235.0674 & 246.2407 & 340.6507 & 261.5098 \\
\hline & $(216.0915)$ & $(227.8269)$ & $(362.8205)$ & (350.4089) & $(353.6414)$ & $(349.5140)$ \\
\hline \multirow[t]{2}{*}{ Rate } & 0.1029 & 0.1272 & -0.2446 & -3.4066 & $-4.0588 *$ & $-4.1957^{*}$ \\
\hline & $(1.4987)$ & $(1.5011)$ & $(1.5290)$ & $(2.3797)$ & $(2.4025)$ & $(2.4029)$ \\
\hline \multirow[t]{2}{*}{ Corrupt } & $282.6434 * *$ & $287.0045^{* *}$ & $257.4096 * *$ & -52.4103 & -15.3078 & -20.9043 \\
\hline & $(120.7101)$ & $(121.3690)$ & $(122.6965)$ & $(118.3746)$ & $(119.9268)$ & $(119.0040)$ \\
\hline \multirow[t]{2}{*}{$\begin{array}{l}\text { RelaX } \\
\text { InGDP }\end{array}$} & & & -56.5704 & & & $30.2441 * *$ \\
\hline & & & $(49.6133)$ & & & $(14.4625)$ \\
\hline \multirow[t]{2}{*}{ Constant } & -291.5776 & -343.9658 & $-1,664.7029$ & -506.6266 & \begin{tabular}{|l|}
$-1,347.0764$ \\
\end{tabular} & -287.5476 \\
\hline & (980.1809) & (991.1395) & $(1,552.6029)$ & $(1,899.5023)$ & $(1,952.2384)$ & $(1,897.1325)$ \\
\hline \begin{tabular}{|l} 
Country \\
fixed effect
\end{tabular} & Yes & Yes & Yes & Yes & Yes & Yes \\
\hline $\begin{array}{l}\text { Time fixed } \\
\text { effect }\end{array}$ & Yes & Yes & Yes & Yes & Yes & Yes \\
\hline Sample & 767 & 767 & 767 & 672 & 672 & 672 \\
\hline R-squared & 0.0969 & 0.0971 & 0.0986 & 0.1194 & 0.1241 & 0.1257 \\
\hline
\end{tabular}

Source: own study.

As shown in Tables 3 and 4, even with the introduction of interaction terms, bilateral relations still have a very strong influence on Chinese ODI to developing countries. The significant positive sign of the variable indicates its impact exerted on Chinese ODI. Besides, the coefficients on both control of corruption and rule of law are positively significant at $5 \%$. This result suggests that Chinese firms would prefer developing host countries which have a good relation with China, especially those with a better legal system.

\footnotetext{
${ }^{4}$ According to the UNDP: Human Development Index released in the 2016 Human Development Report, the United Kingdom, the United States, Australia, Belgium, Canada, France, Germany, Ireland, Japan, South Korea, Spain, Taiwan, Hong Kong, and the Netherlands are considered as developed countries (regions).
} 
As for developed host countries, either bilateral relations or institutions do not significantly affect Chinese ODI. This may because Chinese investment to such locations is mainly motivated by market-seeking. Furthermore, the role of political relations in protecting investment is greatly weakened in countries with better institutions. In contrast, openness and exchange rate now become significant. The more open a host country is, the less investment is attracted to it, indicating the substitution between trade and investment. An increase in real effective exchange rate will make the host countries less attractive by raising both the fixed costs and labour costs.

Table 4. Sub-Sample Results (Institution is proxy by Law)

\begin{tabular}{|c|c|c|c|c|c|c|}
\hline \multirow{2}{*}{ Variable } & \multicolumn{3}{|c|}{ developing countries } & \multicolumn{3}{|c|}{ developed countries } \\
\hline & (1) & (2) & (3) & (4) & (5) & (6) \\
\hline \multirow[t]{2}{*}{\begin{tabular}{|l|} 
Relation \\
\end{tabular}} & $113.6939 * *$ & 112.7771 & $469.8228 * *$ & 6.6449 & 48.5152 & $-182.3087 *$ \\
\hline & $(46.9840)$ & $(83.0493)$ & $(217.3172)$ & $(19.6614)$ & (32.2492) & $(98.5925)$ \\
\hline \multirow[t]{2}{*}{ Open } & -335.7904 & -353.8181 & -469.1001 & $-1,082.2998 * * *$ & 110.8270 & $-1,190.3579 * * *$ \\
\hline & $(389.9926)$ & $(1,401.5888)$ & $(397.5034)$ & $(391.5260)$ & $(827.2472)$ & $(394.5055)$ \\
\hline \multirow[t]{2}{*}{ Rela×Open } & & 2.7910 & & & -176.5045 & \\
\hline & & $(208.4118)$ & & & $(107.8470)$ & \\
\hline \multirow[t]{2}{*}{ InGDP } & 41.0432 & 41.9004 & 500.9635 & 285.3484 & 373.0083 & 300.8351 \\
\hline & $(205.2747)$ & $(215.1642)$ & $(342.2314)$ & (348.9943) & $(352.6038)$ & (348.2739) \\
\hline \multirow[t]{2}{*}{ Rate } & -0.9597 & -0.9616 & -1.5901 & -3.6367 & $-4.1072 *$ & $-4.2688 *$ \\
\hline & $(1.6550)$ & $(1.6617)$ & $(1.6950)$ & $(2.3457)$ & $(2.3600)$ & $(2.3624)$ \\
\hline \multirow[t]{2}{*}{ Law } & $329.6972 * *$ & $329.8629 * *$ & $347.8572 * *$ & -333.6905 & -271.3759 & -274.5732 \\
\hline & $(165.2055)$ & $(165.7860)$ & $(165.3457)$ & $(227.1871)$ & $(230.0459)$ & $(228.6665)$ \\
\hline \multirow[t]{2}{*}{ Rela $\times \operatorname{InGDP}$} & & & $-82.0768 *$ & & & $28.2709 *$ \\
\hline & & & $(48.9035)$ & & & $(14.4564)$ \\
\hline \multirow[t]{2}{*}{ Constant } & -670.9682 & -668.4867 & $-2,552.3425^{*}$ & -304.9296 & $-1,119.8219$ & -150.5285 \\
\hline & (947.5021) & (966.1165) & $(1,466.9737)$ & $(1,897.7640)$ & $(1,959.4582)$ & $(1,895.0023)$ \\
\hline $\begin{array}{l}\text { Country } \\
\text { fixed effect }\end{array}$ & Yes & Yes & Yes & Yes & Yes & Yes \\
\hline $\begin{array}{l}\text { Time fixed } \\
\text { effect }\end{array}$ & Yes & Yes & Yes & Yes & Yes & Yes \\
\hline Sample & 767 & 767 & 767 & 672 & 672 & 672 \\
\hline R-squared & 0.0950 & 0.0950 & 0.0986 & 0.1223 & 0.1261 & 0.1278 \\
\hline
\end{tabular}

Source: own study.

Obviously, the two interaction terms are insignificant for developing host countries, suggesting that the openness and market size will not change the impact of bilateral relations on investment. However, when we look at developed countries, the negative sign of interaction between relation and open suggests that the role of political relations is weakened for countries which are more open. And the positive sign of interaction between relation and GDP indicates that the role of political relations is strengthened. In other words, Chinese firms are attracted to friendly host countries with a large market. 


\section{Robustness Check}

Good political relations help promote bilateral investment, while at the same time bilateral investment is helpful to remove cultural and institutional barriers, thus strengthen bilateral relations. Therefore, it is possible to have reverse causality between political relations and investment, resulting in biased estimates. To deal with this problem, refer to Desbordes and Vicard (2009) and Liu and Yang (2016).We introduce relations lagged by three quarters as the instrumental variable of the political relations in benchmark model. The results of two-stage least squares with instrumental variable are consistent with the above fixed effect model (Table 5). That is, the improvement in political relations could significantly promote Chinese investment, suggesting the robustness of our conclusions.

Table 5. Two-Stage Least Squares Results

\begin{tabular}{|c|c|c|}
\hline \multirow{2}{*}{ Variable } & \multicolumn{2}{|c|}{ ODI } \\
\hline & (1) & (2) \\
\hline \multirow[t]{2}{*}{ Relation } & $15.9887^{* *}$ & 15.8929* \\
\hline & $(6.2776)$ & $(8.2370)$ \\
\hline \multirow[t]{2}{*}{ Open } & $-479.8708 * *$ & $-500.8663 * * *$ \\
\hline & (186.4402) & (168.3689) \\
\hline \multirow[t]{2}{*}{ InGDP } & -8.3903 & 14.9461 \\
\hline & (94.4939) & (104.0801) \\
\hline \multirow[t]{2}{*}{ Rate } & -0.4736 & -0.7484 \\
\hline & $(0.3545)$ & $(0.4691)$ \\
\hline \multirow[t]{2}{*}{ Corrupt } & $112.2548 * * *$ & \\
\hline & (27.7612) & \\
\hline \multirow[t]{2}{*}{ Law } & & $169.1172^{* * *}$ \\
\hline & & $(14.4175)$ \\
\hline \multirow[t]{2}{*}{\begin{tabular}{|l|} 
Constant \\
\end{tabular}} & 290.6023 & 7.8358 \\
\hline & (893.5285) & (997.1727) \\
\hline Observations & 1,439 & 1,439 \\
\hline R-squared & 0.1692 & 0.1692 \\
\hline
\end{tabular}

Source: own study.

\section{CONCLUSIONS}

This article contributes to the literature on the determinants of Chinese ODI. We quantitatively measure the bilateral political relations between China and forty major host countries on monthly basis from 1950 to 2014. Then, building on the literature on political relations or risks and FDI in general, we identify the causal mechanisms of political relations and Chinese outward investment. Using fixed effect regression model, our main findings are consistent with the recent research focusing on political factors explaining China's ODI. The effects of political relations in promoting Chinese investment are varying across countries. It works very well for developing hosts but it seems not to work for developed hosts. Since better political relations complement to the imperfect institutions in developing countries, the risk- 
reduction effect of good political relations is much greater than that for developed countries. There is no evidence for firms investing in countries with high political risks. Even if it is true in few cases, their behaviour can be explained with our model. In addition, investments in developed countries are mainly driven by market or technology, which make the role political relations less important in determining the location of Chinese ODI.

When making investment decisions, Chinese MNEs' do take the bilateral political relations into account. However, it is far from enough. The main policy implications of our findings are that firms should look closely at the interaction between political relations and the institutional environment of a host country, especially hosts with poor institutions. In that case, building the early warning system for political risks is necessary for firms' strategic investment decision. Furthermore, investors should make good use of but not overly depend on bilateral relations, and cooperate with local firms based on the factor endowments. Finally, investing sectors are better to be consistent with the strategy of both China and host countries. For example, with the guidance of 'Belt and Road' initiative and 'Thirteenth Five-Year Plan', the outward investment should focus on the Internet combined with manufacturing, finance, information and communications, smart energy, smart healthcare, transportation and dynamic environmental monitoring services. Also, Chinese and European firms should strengthen their cooperation in areas such as transportation infrastructure, power energy and digital infrastructure within the framework of 'EU Infrastructure Investment Plan' (Juncker plan).

Despite the above contributions, we believe that our empirical research has some limitations that can be addressed in future research. The main limitation may be that certain variables that may also have an influence on location decisions could not be included, such as trade, characteristics of firms and different types of FDI. Depending on a firm's productivity and the motivation of FDI, the political relations linked to each location may play a very different role. For example, firms with higher productivity (i.e. huge fixed costs with economies of scale) seeking strategic asset may be far less reactive to political tensions. In addition to this, due to the availability of data we were unable to evaluate the change of Chinese ODI flowed to Belt \& Road countries driven by the initiative. It will be left for future research when more data are available.

\section{REFERENCES}

Bandelj, N. (2002). Embedded economies: social relations as determinants of foreign direct investment in central and Eastern Europe. Social Forces, 81(2), 411-444. https://doi.org/10.1353/sof.2003.0001

Busse, M., \& Hefeker, C. (2007). Political Risk, Institutions and Foreign Direct Investment. European Journal of Political Economy, 23(2), 397-415.

Busse, M., Kniger, J., \& Nunnenkamp, P. (2010). FDI Promotion through Bilateral Investment Treaties: More Than A Bit. Review of World Economics, 146(1), 147-177.

Davis, C.L., \& Meunier, S. (2011). Business as usual? Economic response to political tensions. American Journal of Political Science, 55(3), 628-646. https://doi.org/10.1111/j.1540-5907.2010.00507.x

Desbordes, R., \& Vicard, V. (2009). Foreign Direct Investment and Bilateral Investment Treaties: An International Political Perspective. Journal of Comparative Economics, 37(3), 372-386.

Du, Q.R., \& Chen, L.Y. (2016). The Opportunities and Challenges of Chinese Enterprises' Investment in Myanmar in the New Government Period. International Trade, (7), 28-31. 
Fornes, G., \& Butt-Philip, A. (2011). Chinese MNEs and Latin America: a review. International Journal of Emerging Markets, 6(2), 98-117. https://doi.org/10.1108/17468801111119470

Gao, J.G. (2011). The Impact of Economic Integration, Political Risks, and Third Country Effects on China's OFDI. Finance and Trade Research, (5), 57-64.

Hanemann, T., \& Rosen, D.H. (2018). Chinese FDI in the US in 2017: A Double Policy Punch. Retrieved from http://cim.rhg.com/notes/chinese-fdi-in-the-us-in-2017-a-double-policy-punch on January 17, 2018.

Hu, Z.S. (2016). International Politics. Central China Normal University Press.

Li, L.L., \& Qi, J.H. (2017). The Avoidance of Political Risk and OFDI Strategic Choice of Chinese Enterprises. Research on Finance and Economics, 43(1), 110-121.

Li, Q., \& Liang, G.Y. (2012). Political Relations and Chinese Outbound Direct Investment: Evidence from Firm- and Dyadic-Level Tests. Research Center for Chinese Politics and Business (Working Paper No. 19). Retrieved from https://ssrn.com/abstract=2169805 on September 28, 2018.

Li, Q., \& Vashchilko, T. (2010). Dyadic Military Conflict, Security Alliances, and Bilateral FDI Flows. Journal of International Business Studies, 41(5), 765-782. https://doi.org/10.1057/jibs.2009.91

$\mathrm{Li}, \mathrm{Q}$. (2006). Political Violence and Foreign Direct Investment. In M. Fratianni \& A.M. Rugman (Eds.), Research in Global Strategic Management-Regional Economic Integration (pp. 225-49). Oxford: Elsevier Ltd.

$\mathrm{Li}, \mathrm{Q}$. (2008). Foreign Direct Investment and Interstate Military Conflict. Journal of International Affairs, 62(1), 53-66.

Liu, X.G., \& Yang, L.X. (2016). Bilateral Political Relations, Host Country Institutional Environment and Foreign Direct Investment. Financial Research, 438(12), 17-31.

Mancuso, J., Dirienzoce, E., \& Das, J. (2010). Assessing terrorist risk and FDI using relative information measures. Applied Economics Letters, 17(9), 787-790.

Meng, X., \& Dong, Y.D. (2015). Socio-Political Risk and Location Selection of Chinese Enterprises' Foreign Direct Investment. International Trade Issues, (4), 106-115.

Pan, Z., \& Jin, Z.K. (2015). Bilateral Political Relations, Host Country System Risks and China's Foreign Direct Investment. Finance and Trade Economics, (6), 85-97.

Quer, D., Claver, E., \& Rienda, L. (2012). Political risk, cultural distance, and outward foreign direct investment: Empirical evidence from large Chinese firms. Asia Pacific Journal of Management, 29(4), 1089-1104. https://doi.org/1089-1104.10.1007/s10490-011-9247-7

The Ministry of Commerce of the People's Republic of China, the National Bureau of Statistics of the People's Republic of China and the State Administration of Foreign Exchange (2016). Statistical Bulletin on China's Outward Foreign Direct Investment. Retrieved from http://fec.mofcom.gov.cn/article/tjsj/tjgb/ on January 17, 2018.

Vladimir, H., Lenihan, B., Andreosso, E., \& Michal, D. (2014). Political Risk, Institutions and Foreign Direct Investment: How Do They Relate in Various European Countries?. World Economy, 37(5), 625-653. https://doi.org/10.1111/twec.12112

Wei, J.F., \& Qian, C.X. (2016). A Study of the Impact of China-EU Bilateral Political Relations on China's OFDI. Journal of Shenzhen University, 33(3), 90-94.

Wei, J.L., \& Chen, Y.G. (2009). The Impact of Political Risk on China's Outward Foreign Direct Investment: An Empirical Study Based on Dynamic Panel Model. Economic Review, (4), 106-113.

Xiao, W., \& Jiang, J.G. (2014). Political Interaction between Top Leaders and the Scale and Relative Fluctuation of FDI in China. International Trade and Economic Research, (11), 30-41.

Xie, M.J. (2015). Study on the Influence of Political Risk on China's Foreign Direct Investment Location Choice. International Economic and Trade Exploration, (9), 66-80. 
Yan, X.T., \& Zhou, F.Y. (2004). Quantitative Measurement of National Bilateral Relations. Chinese Social Sciences, (6), 90-103.

Yan, X.T. (2010). Sino-Foreign Relations Review 1950-2005 - Quantitative Measurement of the Relationship between China and Big Powers. Beijing: Higher Education Press.

Yang, L.X., Liu, X.G., \& Zhang, J. (2016). How do Bilateral Political Relations Affect Foreign Direct Investment, Based on the Dual Margin and the Perspective of Investment Success and Failure. China's Industrial Economy, (17), 56-72.

Zhang, J.H., \& Jiang, J.G. (2012). Research on the Impact of Bilateral Political Relations on China's Foreign Direct Investment. World Economy and Politics, (12), 133-160.

Zhang, J., Jiang, J., \& Zhou, C. (2014). Diplomacy and investment - the case of China. International Journal of Emerging Markets, 9(2), 216-235.

Zong, F.Y., Lu, J.Y., \& Wu, C.Z. (2012). Bilateral Investment Agreement, Institutional Environment, and Location Selection of Foreign Direct Investment in Enterprises. Economic Research, (5), 71-82. 


\section{Authors}

The contribution share of authors is as follows

Lin Zhang 65\% and Xiaoqiong Hao 35\%.

\section{Lin Zhang}

Associate Professor of Economics at School of Business, Shanghai University of International Business and Economics (Shanghai, China). Her research interests include: international investment, innovation and China's cooperation with Central Eastern European Countries (CEECs).

Correspondence to: Lin Zhang, Shanghai University of International Business and Economics, School of Business, 1900\# Wenxiang Road, Songjiang district, Shanghai, China; e-mail: zhanglin@suibe.edu.cn

\section{Xiaoqiong Hao}

Postgraduate student in Shanghai University of International Business and Economics (SUIBE), School of Business; Major in Industrial Economics.

Correspondence to: Xiaoqiong Hao, Flat 3201, Building G1, No. 1 Xue Fu, No. 666 South Qian Hu Road, Yin Zhou District, Ningbo City, Zhejiang Province, China Postal Code: 315199, e-mail: hxqiong0824@126.com

\section{Acknowledgements and Financial Disclosure}

The article is supported by the Center of Central and Eastern Europe Research in Shanghai University of International Business and Economics as part of its 2018 programme (SUIBECCEER2018_03). The views expressed are those of the authors and do not necessarily reflect the views of the Center of Central and Eastern Europe Research.

\section{Copyright and License}

This article is published under the terms of the Creative Commons

Attribution - NoDerivs (CC BY-ND 4.0) License

http://creativecommons.org/licenses/by-nd/4.0/

Published by the Centre for Strategic and International Entrepreneurship - Krakow, Poland 